\title{
МОРАЛЬНІСТЬ ЛЮДИНИ \\ В ЗАГАЛЬНІЙ СИСТЕМІ ДУХОВНОСТІ
}

\section{Трусей Леонід Гаврилович}

Викладач Харківського національного університету повітряних сил

В доповіді розглянуті питання взаємодії культур в моральній області, які найбільш важливі для появи такого феномену, як глобальна культура, щзо неминуче настане у наслідок об 'єктивного процесу глобалізаиіï.

Ключові слова: взаємодія, духовність, мораль, моральність, культура.

По деякій найбільш загальній класифікації, у світі існує три культури: Західна культура, Східна культура, Наша (назвемо її Слов’ янська) культура. Загальна характеристика культур полягає в тому, що усі вони містять три складових (елементи): пізнавальну частину, художню частину і моральну частину. Ці частини різних культур мають природно у своїй основі різні принципи і методи. Взаємодія культур відбувається по таких напрямах: взаємозбагачення, взаємопроникнення, заміщення та ін. В умовах об'єктивного процесу глобалізації логічно говорити про необхідність появи загальної, глобальної культури. Вона повинна з'явитися як цілісна структура в результаті вищеназваних взаємодій перерахованих культур. Принципів взаємодій багато, але ми підкреслимо важливість строгого духовного принципу : «Подібне притягується», Для кожної культури усі їх складові ціннісно орієнтовані. Нас у даному контексті 'цікавить моральна частина. Яким чином відбувається взаємодія саме в моральному аспекті і за яким критерієм, а також де при цьому місце людини. Дамо деякі визначення, необхідні для розуміння суті.

Мораль. Моральним вважається щось правильне в певному суспільстві і в певний історичний момент. Фактично це зведення правил що добре і що погано, закріплених і прийнятих в суспільстві або групі (корпоративна мораль) в законах, правилах, нормах і традиціях. Відомі нам моральні кодекси не є строгими і їх легко пристосовують різні культури, суспільства і люди до повсякденного життя, що в історії часто і робилося, оскільки вони грунтовані не на етичних правилах Природи і тому в них відсутній вищий сенс. 
Моральність. Моральність — це норми, які людина засвоїла (отримала) і застосовує їх ситуаційно в період своєї діяльності. Моральність $є$ направляючою силою. Людина обдарована здатністю пробудитися і отримати потрібні моральні якості із загальної «скарбнички» - духовності.

Духовність. Духовність (iї ще деякі учені [1] називають істинною мораллю) грунтована на принципах Природи і полягає в дотриманні космічних законів, що виходять за рамки людської історії. Ці закони є деяким принципом, вищим сенсом і механізмом діяльності людини. Включає вищі цінності, пов'язані не з діяльністю людини, а із Законами Природи. Ціннісне відношення не виводиться шляхом доказів 3 пізнання сущого [2]. Визначає обов'язок [3, 4]. Визначає любов [2]. Основою соціальної природи людини є духовна спільність [5].

Взаємодії між моральністю, мораллю і духовністю, як елементами системи дуже різноманітні і складні. їх опис займає багато місця. Ми ж обмежимося позначенням деяких, на наш погляд найбільш важливих.

Взаємодія моральність - духовність. Людина в процесі пізнавальної діяльності через саморозвиток своєї особи отримує з духовності якості за універсальним принципом тяжіння і зву. Насправді духовність - це індивідуальна моральна робота по досягненню вищої свідомості, в результаті якої суть людини може бути проявлена через його мозок.

Духовність — це стан свідомості, грунтований не на інтелекті, а на внутрішній сутності людей. Духовність — це практика найвищих людських доброчесностей. Зазвичай духовність асоціюється 3 милосердям і сприйнятливістю людини до хорошої музики і витончених мистецтв, або ж ій надається метафізичний сенс. Таке розуміння духовності не має нічого спільного з високим рівнем внутрішньої дисципліни, якої повинна дотримуватися людина, що поставила своєю метою «перестати бути мостом» і стати надлюдиною.

Насправді людина, що живе відповідно до вищої моралі (духовності), знаходиться в гармонії з Природою. Істинні норми поведінки ніким не вигадані - вони записані в пам'яті Природи і усвідомити їх можна, лише досягнувши стану вищої свідомості [1]. Треба визнати, що більшості людей властивий моральний суб'єктивізм, відповідно до якого метою моральних вчинків вважається досягнення суб'єктивного стану задоволення і щастя. При такому підході поняття моральності не зв’язується з вищим поняттям духовності. Моральний суб' єктивізм набуває все більшого поширення і цьому практично сприяє уся наша система виховання і взаємодії людей з соціумом. 
Взаємодія моральність — мораль. Людина як соціальний суб'єкт і об'єкт збагачує моральну складову культури і порівнює свою моральність в повсякденній діяльності з моральними нормами суспільства. Загальновідома, традиційна мораль грунтована на вірі, спирається на релігійні i ідеологічні принципи, і людина сприймає іiі пасивно і автоматично. Це неминуче веде його до пригнічення інстинктів і імпульсів або до деструктивних емоцій — таким, як відчуття провини, якщо вчинки людини суперечать моралі. Пригнічення шкідливі і небажані, тому що з часом в підсвідомості людини утворюється справжній «диявольський котел», тому сублімація інстинктів буде найкращим рішенням. Справжня мораль має бути грунтована на розумінні і обдуманому виборі людиною свого світогляду.

Традиційна мораль має виключно репресивний характер і $є$ механізмом, за допомогою якого людина намагається виключити або загнати в підсвідомість думки, образи і спогади, пов'язані з інстинктивними імпульсами, породженими нашим «воно». Треба сказати, що самоуки, люди, що добилися знань і самовиховання в результаті вільно прийнятого рішення без сторонньої допомоги, набагато відрізняються в плані психічних рис, характеру і волі. Величезні зусилля, зроблені ними сприяли розвитку нового людського змісту, часто ними неусвідомленого. Будь- яка справжня моральність має бути вільною, добровільною і свідомою, тобто стати етичним завоюванням людини, зведенням норм, засвоєних вільно і понятих кожним окремо. Існує єдиний вірний шлях досягнення вищої моральності індивідуальна робота, що дозволяє підвищити рівень свідомості людини і отримати доступ до глибинної трансцендентальної духовності.

Взаємодія мораль - духовність. На наш погляд взаємодії проходять через людину. Людина, черпаючи і збагачуючи свою моральність 3 духовності, тим самим змінює моральні норми суспільства. Мета нашого життя - еволюція індивідуальної свідомості, що полягає в розвитку істинно людських-якостей, що відрізняють нас від тварин. Але ця мета була забута в гонитві за всілякими чуттєвими задоволеннями. Ми завжди творимо, оскільки психічна енергія створюється нашими думками, почуттями і вчинками, є імпульсами біофотонів, які випромінюються в простір, впливаючи на сили Природи, при цьому ми також випробовуємо на собі їх вплив. Кожна частинка людини, випромінюючи біофотони, змінює Природу і натомість отримує енергію, яка відновлює космічну рівновагу, порушену нашими діями. 
Якщо випромінювання людини конструктивні, позитивні і гармонійні, то після зачаття в череві Природи вони компенсуються чимось еквівалентним, оскільки подібне притягує подібне. Якщо енергетичне випромінювання людини було руйнівним, нечистим, дисгармонійним, або злочинним, природна рівновага зажадає такої ж негативної, але значно сильнішої реакції відносно неї. Це буде справедливим покаранням за порушення моралі. «Що посієш, то і збереш». Людина отримає покарання за поганий вчинок незалежно від того, чи був його первинний намір добрим або злим.

Поняття єдності Всесвіту не нове. Ще Арістотель стверджував, що порядок у Всесвіті грунтований на взаємодії усіх ії частин так само, як в живому організмі. У роботах сучасного вченого Дзвида Бома також говориться про структурну єдність Всесвіту [6]. Людина в результаті своєї Поняття єдності Всесвіту не ново. Ще Арістотель стверджував, що порядок у Всесвіті грунтований на взаємодії усіх іiї частин так само, як в живому організмі. У роботах сучасного вченого Дзвида Бома також говориться про структурну єдність Всесвіту [6].

Людина в результаті своєї діяльності, яка освячена високою моральністю, працюючи сільським трудівником в полі, на підприємстві, в школі або в ВНЗ, керівником великих і малих колективів, привносить до моральних норм суспільства і свою, індивідуальну частинку.

Висновки. Наявність навіть найвищих моральних якостей окремих індивідів самі по собі нічого не змінять в суспільстві в сенсі моралі. Змінити можуть люди тільки тоді, коли будуть відповідні взаємодії як між окремими людьми, так і між окремими стратами соціуму. Значущість результатів взаємодій значно зростає якщо вони закінчуються структуризацією окремих елементів взаємодій з появою деякої цілісності, що має нову якість. Це і повинно бути темою подальших досліджень.

\section{Література}

1. Дарио Салас Соммэр. Мораль XXI века. К.: София, 2004.

2. Батищев Г. С. Найти и обрести себя. Вопросы философии. № 3. М., Наука, 1995.

3. Кант И. Метафизика нравов в двух частях. Т. 4. Соч. в 6 тт. М., 1969.

4. Фихте И. Г. Назначение человека. Сочинения в 2 т., Т.2., СПб, 1993.

5. Бердяев Н. Зкзистенциальная диалектика божественного и человеческого. Париж, 1952.

6. David Bohm. La totalidad y el orden implicado, Editorial Kairos, Barcelona, 1992. 